\title{
Teachers' Perceived Value, Motivations for and Adoption of Open Educational Resources in Animal and Food Sciences
}

\author{
http://dx.doi.org/10.3991/ijet.v10i2.4427 \\ A. Algers ${ }^{1}$ and A. Silva-Fletcher ${ }^{2}$ \\ ${ }^{1}$ Swedish University of Agricultural Sciences, Skara, Sweden \\ ${ }^{2}$ Royal Veterinary College, Hatfield, UK
}

\begin{abstract}
Teachers' motivations behind their view on value and adoption of open educational resources (OER) were investigated based on 101 questionnaire answers from teachers in animal welfare, animal science and food science. A factor analysis uncovered the underlying dimensions for teachers' motives and indicated that they were complex and linked to subject area. Underlying dimensions for the motives to adopt OER were identified at three levels; individual (e.g. altruism), institutional (e.g. collaboration with peers), and societal (e.g. reaching beyond borders of the academy). The underlying dimensions for the inhibitors for adoption at individual and institutional level were challenges regarding individual competences, quality assessment and teaching practices. When using activity theory, an affinity space could be identified for teachers in animal welfare with its own norms and expectations with regards to the open educational practices. The results suggested that sharing for the benefit of others and collective collaboration with other peers were stronger incentives for teachers in the specific subject of animal welfare than it was for teachers in broader and less contested subject areas. Animal welfare teachers also had low agreement with problems such as OER being deviant to higher education and for being difficult to adapt to teaching context, and these teachers also had a higher adoption rate than other teachers. Furthermore, this study provides evidence that OER challenges the boundaries of higher education and that an affinity space can enable OER adoption.
\end{abstract}

Index Terms-Activity theory; Affinity space; Altruism; International survey; Subject specific.

\section{INTRODUCTION}

Recent studies have analysed the enablers and inhibitors for sharing OER, without regard to the subject, by teachers [1;2] and students [3], but studies on the reasons for sharing OER among teachers need to be specific to a subject area in order to understand the context and be able to generalize the findings [4]. This study focuses on sharing and more broadly on adoption of OER within the subject areas of food science, animal science and animal welfare. The subject area of animal welfare is relatively new and expanding [17], and also contested, compared to agriculture and food sciences that are broader and more established scientific areas. The term adoption of OER is used in this paper as "the wide range of overall practices including creation, use/re-use, revising, re-mixing, and redistributing of OER" [5].

Educators' and students' attitudes towards sharing OER are dependent on their motivations to share $[2 ; 3]$. Their motivations for sharing are according to the social exchange theory either intrinsic, such as altruism, satisfaction and enjoyment, or extrinsic, such as financial gain or social reputation [3]. Furthermore, intentions to engage in activities are dependent on attitudes, but need to be specific to a behaviour in order to have predictive power $[6 ; 3]$, e.g. attitudes about the environment were unrelated to recycling behaviour but a more specific attitude about recycling could predict recycling behaviour [3].

An important intrinsic determinant for sharing OER is altruism [2]. Altruism is the principle or practice of concern for the welfare of others [3] and the welfare of others in this paper twofold, meaning both the welfare of humans and the welfare of animals. It can be seen as sacrificing something for someone other than the self, e.g. sacrificing time or energy, with no expectation of any compensation or benefits. At the human level, this can be illustrated by sharing OER with no expectation of receiving recognition for the act of giving [3] and at the animal level, improving animal welfare by sharing ideas within this subject with other humans through OER, again with no expectation of receiving recognition.

Satisfaction and enjoyment related to social exchange are other important predictors for teachers' intentions to share $\lceil 2\rceil$ but the motivational factors for sharing OER seem to be highly complex and need to be considered in conjunction with the purpose of reuse and the context of the resource, such as discipline based community sharing $[7 ; 8]$.

Altruism, satisfaction and enjoyment constitute intrinsic motives for sharing, which is argued only to be relevant within a community [9], although satisfaction also can come from the act of creative self-expression [10]. The OER adoption is argued to increase because of niche communities within specific disciplines in highly motivated networks [8] and because it supports "passion-based learning" [11]. Niche communities have been described by [12] as communities gathered around a specific subject or passion. "Ref. [13]" uses the concept "affinity space" to describe a space organized around an interest which people have an affinity for. Contributing to the collective knowledge through interactions among participants in such a space is found to be more important than the knowledge of individual participants per se [14; 15].

"Ref. [2]" found that only intrinsic factors were important predictors for intentions to share OER, and the authors concluded that extrinsic reward systems will have limited effect on teachers' willingness to share. Inhibitors for sharing are related to tensions within the academy and 
between academies and are affected by established structures and practices. Reusing of OER created by others is hard and time consuming [16] but is facilitated by relying on the reputation of the individuals who created them or recommended them, or by relying on the organizations that these individuals belong to [1]. However, today's problems are argued to be too complex to trust individual experts and are calling for knowledge communities rather than for expert individuals [15]. Therefore, we argue that affinity is a prerequisite for OER adoption, requiring networks of peers with the same interests and goals.

In affinity spaces the idea of sharing OER creates value because of several reasons. First of all, it is a way to be in dialogue in the open, which has particular importance for institutional representatives in contested areas of societal relevance. Secondly, sharing and collaborating on the creation of OER is a social culture creating satisfaction for teaching staff in the otherwise solitary profession [12]. Thirdly, it can be argued both from a non-academic and from an academic view, that the power of participation in an affinity space can be harnessed and give a sense of equality [11].

It has been suggested that animal welfare can form the basis for such an affinity space [18]. Firstly, it is gaining momentum as a topic of interest to the international community who are involved in teaching and research with different species of animals; farm animals for food production, research animals, and companion animals. The individuals involved in animal welfare are often committed to their work since many see themselves as advocates for animals as a vulnerable group and influence the society through developing new scientific results, feeding the legislative authorities with evidence [19], participating in the societal debate, and through teaching. Secondly, it is a topic of significance to many citizens and consumers; in particular between young people and students [20].

Teaching in animal welfare has undergone a paradigm shift from teaching based purely on lectures to a mixture of lectures and participatory activities such as ethical discussions emphasizing reflections of societal relevance [21]; or in other words from acquisition of knowledge to a more participatory approach [22]. Generally, the Internet can potentially change the view from transfer of content to share and mutually construct content through participatory activities, which is a social view on learning [11]. Thus, research on OER has to change from how OER can be accessed to how OER can be created, incorporated and be of value in educational practices.

Since only a few studies have been conducted on OER in food and animal science [e.g. 23; 24], and we are not aware of any studies on adoption of OER in animal welfare, we contribute to fill this gap with this study.

Motivations are difficult to measure through surveys but respondents' agreement to a battery of statements can indirectly be used for measuring underlying dimensions of motives in favour of or against the adoption of OER. The intention of this study is to examine these underlying dimensions of motives to share and adopt OER in animal welfare and food science and to follow up the few existing studies that analyze sharing and adoption of OER by teachers in higher education, by addressing the issue of subject area specificity.

The third generation activity theory [25] is used as a lens to study value, sharing and adoption of OER within these specific domains of higher education. Activity theory has recently been used in the analysis of sharing OER, but individual motivations need to be explored further [26]. This study aims to examine: 1) What are teachers' values of OER and what are teachers' motivations? 2) How are values, motivations and adoption related? 3) How and why adoption of OER varies in the fields of animal and food sciences, and especially animal welfare.

\section{A. Literature Review}

Firstly, we discuss the state-of-the-art in teaching food science and after that we have a closer look at the teaching in animal welfare with its specific conditions.

A review of trends in food science education in Europe indicated a diversity of teaching and learning in food science and a movement towards student centred approaches but pointed at a continuous need of change and emphasised the exchange of experience in the network of teachers [27]. However, a shift towards student centred and collaborative learning in food science was described some years earlier in USA [28]. This approach is also a common way to introduce first year's students to food science, since it gives them a broad knowledge base and a "handson" derived frame of reference that can be utilized in subsequent courses [29].

Continuing education in food science is widespread and numerous examples of distance education in food science to employees in the food sector have been documented [e.g. 30], but not much research has been published about the use of learning resources in this subject area. A few articles focus on OER as an artefact with the aim to facilitate knowledge on food science for employees in third world countries $[23 ; 31]$ but the potential for OER in food science is not sufficiently investigated. It has been shown that most of the European consumers have concerns related to their choice of food [e.g. 32]; but food science is a broad subject area, since it covers food items based on both animals and plants and includes subjects related to production, processing and consumption. It becomes even more complex when it embraces ethical dimensions, such as climate change, sustainability, fair trade, and GM food. Hence, we argue that there is a large potential of OER in these food related subject areas.

It has also been argued that there is potential for OER in veterinary medicine [24] and in animal welfare [18]. One prospective is the growing interest between consumers and citizens in how farm animals are used for the production of food, 'how well the animals fare' in these production systems and how the welfare of animals can be improved [20]. Thus, farm animal welfare is a contested subject area, characterized by a multiplicity of stakeholders with conflicting interests, and the definition of and view on animal welfare differs between individuals, situations and times $[33 ; 34]$. Since animal welfare has become increasingly transparent, retailers, processing industries, restaurants and farmers are heavily affected by the public interest in animal welfare, and governments, NGOs and governmental and international organisations are increasingly involved in the debate on animal welfare [35]. Because the trade of animals and animal foodstuffs and the scientific domain of animal welfare are global, the subject area needs to embrace a global mindset and another prospective is that researchers and teachers in animal welfare bring the discussions and negotiations in a global community and context [33]. 
Hence, the scientific issues of animal welfare are of high societal relevance, demanding new and solid scientific evidence and normative ethical discussions on what the society accepts as good animal welfare. Research and teaching in complex issues such as sustainable development are in need of a collective and participatory angle entry [36] and animal welfare is an aspect of sustainable development [34]. Because of the unpredictability and uncertainty in how these subjects will develop due to societal and normative changes in addition to increased scientific evidence, [36] argue that an inclusive and collective attitude is necessary for sustainable development.

Teaching in animal welfare was until the late 90s dedicated to 'measurement' of animal welfare as if it is purely an empiric property. This concept changed at the turn of the century when it became evident that animal welfare is inherently a normative concept. Today the assessment of animal welfare is based on value notions of what is better or worse for an animal [37], which has changed the scientific field and the teaching approach to a more value based foundation. Since the discipline nowadays combines natural sciences and normative considerations, the teaching is most commonly grounded in discussions of current case-studies and sometimes in formal debates and role-play [21]. Thus, teachers need to be able to articulate ethical negotiations on how science fits into the social debate [37], but not all animal scientists feel confident in conducting such ethical discussions. Therefore, there seem to be a need for case studies in the subject area of animal welfare and of learning resources that can be shared to scaffold ethical discussions, but very few such OER are available [18].

Based on the literature we propose that the adoption of OER in teaching and learning in food science and animal welfare is low but may have great potential. The adoption of OER has the potential to support learners within these subject areas but it depends not only on the content of the resources but also and especially on how they are used [15]. With regard to teachers in food and animal science and animal welfare, there have been no systematic investigations on the use or adoption of OER, the reasons for or against such adoption or how the use of OER can be linked to motivations. Therefore, it is of interest to know how higher education teachers within these areas value and use OER, and if there are any differences between the teachers of animal welfare, animal science and food science.

\section{B. Theoretical Perspective}

In this study we will be using what is referred to as third-generation activity theory as proposed by Engeström [25]. Activity theory has been used for evaluating online collaborative learning activities in other disciplines [38; 39; 40].

Activity theory defines two planes of analysis when identifying bounded systems of activity; the internal and the external planes. The internal plane of actions refers "[... to the human ability to perform manipulations with an internal representation of external objects before starting actions with these objects in reality" [47, p. 51]. Some researchers divide the analysis in three planes; the personal, the interpersonal and the collective global activities taking place at the institutional or community plane [55].

Activity theory is used in this study to interpret data on the activities taking place at both the personal plane and at the external plane, and we follow the recommendation to analyse one plane at a time [56]. The object of the activity is the reason why individuals and group of individuals choose to engage in an activity. The object of activity in this study is the adoption of OER. However the more detailed interpretations of the object can vary, and refer to the motives for participating, the goals of the activity, or the material products that participants are gaining from the activity [55].

In the defined activity system, we first analyse the objective to which teachers direct their activities, based on their motives for adopting OER. Leontiev distinguished the object of activities in two different meanings, described as predmet (Russian), as a special status acquired by things that opposes object, which is a physical thing [57]. The special status was exemplified by Leontiev as "the object of labour" or "the object of contemplation" [58, p. 49].

The predmet of activities are according to Leontiev the motivations or "the true motive", thus a motivation is a drive behind an act and a goal is a more shallow reason for the activity [57]. Therefore, individuals also act differently whether their motivations or their goals are frustrated [47]. He explains that if a goal is frustrated it is necessary to set new goals, which is often done without any negative emotion, whereas if a motivation is frustrated, people get upset (ibid). We analyse the internal plane by identifying motivations as well as tensions and contradictions within the activity system. The intention has been to divide benefits, incentives, problems and barriers in personal and non-personal dimensions.

Secondly, we analyse the actions at the external plane, which are related to the OER as material products. Thus we analyse if the individuals in this study have different conscious goals of the activity; if they act differently oriented to the goal or use different kinds of material products.

Activity theory further argues that activities are always social, including those that are not carried out collectively [571. Subjects are grouped into communities, with rules mediating between subject and community and a division of labour mediating between object and community [25]. A community, itself, may be part of other communities, and a specific community may have norms and conventions that constrain actions and interactions within their specific activity system [25]. We analyse if a subcommunity, or an affinity space, can be identified within the community of higher education teachers in this study.

In activity theory the core mechanism implies that the individuals gain agency and take charge of the process [44], in other words that they realize intentions based on motivations and perform activities. Agency is an issue that has been underplayed in the activity theory but recent studies have indicated how agency emerges in interactions and that agency lies in the relationship between individuals rather than within the individual $[44 ; 45]$. Thus, agency in relation to OER adoption is of interest [26] and therefore we explore agency related to the creation, use and remix of OER.

\section{MATERIAL AND METHODS}

This study is based on a self-completion online survey that included 23 statements regarding OER. The survey focused on the value and adoption of OER; demographic 
information was also included. The results are presented in the article in the same order as the statements were asked in the survey.

The target group for the survey was an international network of researchers and teachers from 52 institutions that had worked together in an EU-project on the development of innovative, integrated, and sustainable food production. Part of the project was focusing on teaching and the authors of this manuscript were responsible for the creation of OER in animal and food science. The participants in this international network were involved in animal and food science and some were directly involved in animal welfare. The survey was sent to 218 individuals who were identified within this network and included individuals involved in the field of animal welfare, animal production, and food science. The introduction to the survey made it explicit that it was targeting teachers and trainers, and therefore it is anticipated that every respondent had teaching obligations.

The survey was conducted during the period between June and September 2012, and three reminders were sent via emails. For analystical purposes there are only two groups, teachers of animal welfare and others, which were teachers in other subjects of animal science and in food science and related areas.

Statements on value of OER were separated as general benefits and problems at institutional level and personal incentives and barriers. Statements on adoption of OER were separated as use, sharing and creation. Teachers' values were measured based on previous work by [1].

\section{A. Data Analysis}

Exploratory factor analysis was used to identify underlying dimensions for the motives. Agreements on statements about the value of OER were given at a scale and missing values were substituted with the mean value of the scores of the specific answers. In order to achieve a robust structure, different component solutions were assessed, using Varimax-rotated principal component analysis, based on the eigenvalues being larger than 1 and the scree plot. A few items were excluded because of low technical quality, e.g. that the respondents had difficulties understanding the question or because they were not discriminating, e.g. that almost everybody totally agreed. After applying these guidelines, the best solution for a factor structure model, based on the remaining items, were identified.

\section{RESULTS}

A total number of 132 answers to the survey were retrieved, of which 18 were repetitions and 13 only included demographic information. Thus, the study had 101 observations leaving a response rate of $46 \%$, but all respondents did not fully complete the survey, $100 \%$ answered questions on teaching practices, $85 \%$ answered questions on value of OER and 85 to $36 \%$ on adoption of OER. The 101 responders were based in 23 countries on 4 continents.

\section{A. Value of OER}

Eighty six respondents answered to which extent they agreed to statements about value OER, and these statements were divided in value at a general level to the phenomenon (benefits and problems) and in value for own institution and personal practices (incentives and barriers).
Finally, they also responded to statements about incentives for the creation of OER. The questions on value of OER were based on the Likert scale; 1=Don't agree, 2=Agree slightly, 3=Agree moderately, 4= Totally agree; and other questions were based on multiple indicator measures; $0=$ No and $1=$ Yes.

A factor analysis of the statements on benefits of using OER revealed three underlying dimensions (Table I). The item"It is a way to leverage on taxpayers' money" was omitted, since the responders did not understand this statement. The best solution for a factor structure model defined three components. Factor one can be interpreted as expression of outreach (OUT), factor two as an expression of a collective institutional enterprise dimension (COL), factor three as an expansive teaching approach (EXPA). The items with the strongest loading on the outreach-factor are about dissemination, but also the question of free and democratic access has a high loading. An interpretation of this factor is that one type of benefit of OER is that it is a means to reach out to society by giving free access to scientific knowledge in an effective and democratic way. The collective institutional enterprise dimension is loaded by statements about OER as a means to collaborate with peers and draw on collective expertise. Also the statement about stimulating institutional improvement has a high loading. These statements emphasize the collective and institutional benefits of working with OER. OER is a means to improve institutional collaboration. Finally, the expansive teaching dimension is primarily loaded by statements about OER as a way of attracting students and promoting lifelong learning. The third statement with a substantial loading is about the attractiveness of OER to students. An understanding of this factor is that OER is a means to expand education by being attractive to students.

Looking at the individual items, statements about OER as a way of promoting lifelong learning and free education for everybody have the highest degree of agreement. These statements are opinions at a policy level that most academics can support. They also to a high degree agreed to the benefit of using OER as a way of utilizing a collective expertise. It should be noted that all the mean values except one were between 3 and 4 (3=Agree moderately, 4=Totally agree), even though benefits related to dissemination had the lowest agreement (Table I).

A factor analysis of the statements on the general problems of using OER indicated three underlying dimensions (Table II). Factor one captures a concern for quality assessment (ASS), factor two a concern for OER being a deviance in higher education (DEV), and factor three a concern for pedagogical adaptability (PED). The item with strongest loading on the quality assessment-factor is about the difficulties in assessing quality, but also the statement about everybody can modify which will affect the accuracy has a high loading. This factor can be interpreted as a concern related to the dynamic nature of OER that challenges the established structures within the academy such as peer review of scientific information.

The items with strongest loading on the deviance-factor are about OER being a fad, but also that copy-right issues are unclear.

An interpretation of the deviance factor is that OER is challenging the social norms and rules in the otherwise robust academy. The pedagogical adaptability dimension 
has high loading by two statements that express difficulties with adapting OER to the target group and to the model of teaching. These statements emphasize that OER is too static, since it is not tailored for the specific context.

Of the individual items, the statement about that copyright issues are unclear has the highest degree of agreement. This is a problem that generally evokes debate in the academy. All the three statements about quality assessment had high degree of agreement, including how accurate and current the information is. Except the item about copy-right the mean values for the items loading on the deviance-factor (it is not a sustainable alternative, it is a competitor to regular education and it is a fad that will die soon) are between 1 and 2 (1=Don't agree, $2=$ Agree slightly). The statements about problems related to adapting the OER to a specific context also have high degree of agreement.

A factor analysis on the statements on personal incentives for using OER revealed two underlying dimensions (Table III). Factor one can be interpreted as an expression of collective and collaborative teaching approach (COL), and factor two as expectations coming with new digital teaching approaches (EXP). Four of the items loading on the collective-collaborative-factor are strong and they are about utilizing expertise in the research community, strengthen the research base through collaboration in order to improve teaching and making it more research based. The items with strongest loading on the expectation-factor are that "my students like digital resources", but also the statements about that OER reduces cost for my institution and is a way to attract more students to my courses have high loading. The expectation factor can be interpreted as emphasizingboth the attempts to live up to external and internal expectations.

Looking at the individual items in the first factor, statements about utilize expertise of research community and supplementing own teaching have the highest degree of agreement. The respondents also to a high degree agree on the incentive that their students like digital resources, and thus seeing OER as a way to satisfy students.

A factor analysis of the statements on personal barriers for adopting OER revealed three underlying dimensions (Table IV). Factor one can be interpreted as expression of a concern for quality assessment and for using OER across cultural and linguistic boundaries (ASS), factor two as a concern for pedagogical adaptability (PED), and factor three as an expression of confidence in own competence about new digital teaching approaches (COCO). Three items have strong loading on the quality assessmentfactor, which are concerns for quality, accuracy and how current the information is. The items with strongest loading on the pedagogical adaptability factor are about concerns for adaptability to culture and target group. Finally, the two items loading on the confidence in own competence-factor both have high loading and are related to usage of OER and copy-right issues.

The individual items related to personal barriers having highest agreement are the personal competences in how to handle copy-right and difficulties in assessing the quality and accuracy of OER.

Finally, a factor analysis of the statements on the specific incentives for the creation of OER revealed two underlying dimensions (Table V). This analysis was done on
TABLE I.

BENEFITS AT GENERAL LEVEL OF ADOPTING OER DIMENSIONALITY AND DESCRIPTIVE DATA

\begin{tabular}{lcccccc}
\hline & OUT COL & EXPA & M & SD $^{\mathbf{A}}$ & N \\
\hline $\begin{array}{l}\text { Education should be free for } \\
\text { everybody }\end{array}$ & $\mathbf{. 6 8}$ & -.04 & .07 & 3.40 & 0.87 & 83 \\
$\begin{array}{l}\text { It is a way to conduct cheap } \\
\text { research dissemination }\end{array}$ & $\mathbf{. 8 4}$ & .15 & .06 & 2.89 & 1.03 & 82 \\
$\begin{array}{l}\text { It is a way to conduct fast and } \\
\text { global research dissemination }\end{array}$ & .79 & .28 & .10 & 3.16 & 0.95 & 80 \\
$\begin{array}{l}\text { It is a way to utilize a collective } \\
\text { expertise }\end{array}$ & .14 & $\mathbf{. 7 8}$ & .02 & 3.37 & 0.70 & 80 \\
$\begin{array}{l}\text { It is a way to collaborate with } \\
\text { peers }\end{array}$ & .08 & $\mathbf{. 8 3}$ & .01 & 3.35 & 0.72 & 77 \\
$\begin{array}{l}\text { It is a way to stimulate institu- } \\
\text { tional improvement }\end{array}$ & .12 & $\mathbf{. 6 7}$ & .16 & 3.23 & 0.81 & 76 \\
$\begin{array}{l}\text { Students like digital resources } \\
\text { It is a way to promote lifelong }\end{array}$ & -.01 &. .50 & $\mathbf{. 5 9}$ & 3.21 & 0.79 & 81 \\
$\begin{array}{l}\text { learning } \\
\text { It is a way to attract more stu- }\end{array}$ & .11 & -.08 & $\mathbf{. 7 9}$ & 3.61 & 0.70 & 82 \\
\end{tabular}

It is a way to attract more stu-

dents

$\begin{array}{llll}\% \text { explained variance } & 20.5 & 23.4 & 18.6\end{array}$

${ }^{\mathrm{A}} \mathrm{High}$ mean score means high agreement

TABLE II.

PROBLEMS AT GENERAL LEVEL OF ADOPTING OER DIMENSIONALITY AND DESCRIPTIVE DATA

\begin{tabular}{|c|c|c|c|c|c|c|}
\hline & ASS & DEV & PED & $\mathbf{M}$ & SD $^{A}$ & $\overline{\mathbf{N}}$ \\
\hline $\begin{array}{l}\text { It is difficult to assess if } \\
\text { the quality is good }\end{array}$ & .84 & -.10 & .16 & 2.76 & 0.93 & 75 \\
\hline $\begin{array}{l}\text { It is open for everybody to } \\
\text { modify - affect accuracy }\end{array}$ & .77 & .32 & .03 & 2.64 & 1.03 & 76 \\
\hline $\begin{array}{l}\text { It is difficult to assess how } \\
\text { current the information is }\end{array}$ & .57 & .48 & .11 & 2.67 & 0.89 & 76 \\
\hline $\begin{array}{l}\text { It is not a sustainable } \\
\text { alternative }\end{array}$ & .23 & .57 & .38 & 1.82 & 1.01 & 77 \\
\hline $\begin{array}{l}\text { It is a competitor to regular } \\
\text { education }\end{array}$ & .30 & .53 & .26 & 1.86 & 1.00 & 77 \\
\hline It is a fad that will die soon & -.15 & .80 & .30 & 1.27 & 0.64 & 75 \\
\hline $\begin{array}{l}\text { The copy-right issues are } \\
\text { unclear }\end{array}$ & .23 & .75 & -.25 & 2.79 & 1.06 & 66 \\
\hline $\begin{array}{l}\text { It is difficult to adapt to a } \\
\text { specific target group }\end{array}$ & .08 & .10 & .88 & 2.33 & 1.05 & 80 \\
\hline $\begin{array}{l}\text { It is difficult to adapt to a } \\
\text { specific model of teaching }\end{array}$ & .13 & .13 & .85 & 2.10 & 0.91 & 80 \\
\hline$\%$ explained variance & 20.7 & 24.2 & 21.1 & & & \\
\hline
\end{tabular}

TABLE III.

PERSONAL INCENTIVES FOR ADOPTING OER DIMENSIONALITY AND DESCRIPTIVE DATA

\begin{tabular}{|c|c|c|c|c|c|}
\hline & COL & EXP & M & SD $^{A}$ & $\mathbf{N}$ \\
\hline $\begin{array}{l}\text { It is a way to utilize expertise of } \\
\text { research community in my courses }\end{array}$ & .79 & -.01 & 3.28 & 0.71 & 81 \\
\hline $\begin{array}{l}\text { It is a way for me to collaborate } \\
\text { with peers }\end{array}$ & .69 & .30 & 2.94 & 0.83 & 78 \\
\hline $\begin{array}{l}\text { It is a way to make my teaching } \\
\text { more research-based }\end{array}$ & .72 & .29 & 2.70 & 1.05 & 80 \\
\hline $\begin{array}{l}\text { It is a good complement to my own } \\
\text { teaching }\end{array}$ & .77 & .14 & 3.30 & 0.79 & 80 \\
\hline $\begin{array}{l}\text { It is a way to stimulate improve- } \\
\text { ment in my institution }\end{array}$ & .78 & .17 & 3.11 & 0.90 & 74 \\
\hline It reduces cost for my institution & .04 & .71 & 2.59 & 1.11 & 76 \\
\hline $\begin{array}{l}\text { It is a way to attract more students } \\
\text { to my courses }\end{array}$ & .35 & .67 & 2.50 & 1.00 & 76 \\
\hline My students like digital resources & .16 & .80 & 3.11 & 0.81 & 76 \\
\hline$\%$ explained variance & 37.1 & 22.8 & & & \\
\hline
\end{tabular}


a subset of the data, consisting of the individuals who have been creating OER. Factor one can be interpreted as an expression of a systemic academic agency dimension (ACAG), factor two as societal benefits of knowledge sharing outside the academy (SOBE). The item with the strongest loading loaded on the societal benefit-factor and is "I want to share this for the benefit of others". This underlying factor for creation of OER has a democratic dimension. The other item loading on the societal benefitfactor, the will to transfer theoretical research results into practical applications also has strong loading. The item with strongest loading on the academic-agency-factor is that "I want to gain in reputation", but even the items "I want to collaborate with peers" and to stimulate institutional improvement have strong loading. The academic agency-factor can be understood as an expression of a combination of individual positioning in the academy and social activities dealing with the development of institutional operations, which is in opposition to the underlying factor for sharing outside the academy with public benefit as a goal.

Looking at individual items, the statement "I want to collaborate with peers" has the highest degree of agreement in the first factor. The statement "I want to share this for the benefit of others" has a very high degree of agreement in the second factor, close to 4=Totally agree. The statement with lowest degree of agreement was to gain in reputation through the creation of OER.

An additional analysis was conducted on the differences between teachers in the subject of animal welfare and other teachers (Table VI).

Two dimensions were significant different between subject areas, namely problems with OER as a deviant object, and pedagogical adaptability as a personal barrier to use OER. Teachers in animal welfare did not see OER as an abnormal phenomenon in higher education and did not agree on integration of OER in teaching practices to be a problem to the same degree as other teachers.

When comparing teachers in animal welfare with others the pattern is that teachers in animal welfare generally agree more with statements on enablers and less with statements on inhibitors, whereas the opposite is typical for other teachers. These results should be seen in relation to the adoption rate of OER between subject areas.

The agreement with individual items on incentives for creating OER was in some cases significant different depending on teaching subject (the specific items are not included in the table). The altruistic statement that "I want to share this for the benefit of others" was the incentive for creation that had the highest agreement and had higher agreement between teachers in animal welfare than between other respondents $(p<0.05)$ and teachers in animal welfare were more involved in the creation of OER $(p<0.001)$. There was also a higher agreement with the statements to collaborate with peers and to transfer theoretical results into practical applications between teachers in animal welfare than between other teachers $(p<0.05)$. Having analysed the underlying dimensions for the motives for adoption an important follow up is the result on adoption of OER.
TABLE IV

PERSONAL BARRIERS FOR ADOPTING OER DIMENSIONALITY AND DESCRIPTIVE DATA

\begin{tabular}{|c|c|c|c|c|c|}
\hline & ASS & PED & $\mathrm{COCO}$ & $\mathbf{M}$ & $\mathbf{S D}^{\mathbf{A}} \mathbf{N}$ \\
\hline I can't meet the authors personally & .45 & .26 & .35 & 1.69 & 0.9180 \\
\hline I can't be sure of the quality & .93 & .04 & .13 & 2.36 & 0.9081 \\
\hline I can't be sure of the accuracy & .95 & .09 & .04 & 2.35 & 0.8981 \\
\hline $\begin{array}{l}\text { I can't be sure how current the } \\
\text { information is }\end{array}$ & .90 & .10 & .05 & 2.28 & 0.8982 \\
\hline $\begin{array}{l}\text { It is not a sustainable alternative for } \\
\text { my teaching }\end{array}$ & .51 & .36 & .14 & 1.87 & 1.1080 \\
\hline $\begin{array}{l}\text { I can't use English material, my } \\
\text { students find it hard to read English }\end{array}$ & .28 & .66 & .11 & 1.56 & 0.9681 \\
\hline $\begin{array}{l}\text { I would rather use material devel- } \\
\text { oped in my own culture }\end{array}$ & .10 & .85 & -.04 & 1.73 & 0.9682 \\
\hline $\begin{array}{l}\text { I don't know how to adapt it to my } \\
\text { target group }\end{array}$ & .06 & .82 & .11 & 1.65 & 0.8881 \\
\hline $\begin{array}{l}\text { I don't know how to adapt it to my } \\
\text { model of teaching }\end{array}$ & .07 & .78 & .21 & 1.64 & 0.8681 \\
\hline $\begin{array}{l}\text { I would need training in how to use } \\
\text { the OER }\end{array}$ & -.05 & .42 & .75 & 2.16 & 1.0880 \\
\hline $\begin{array}{l}\text { I don't know how to handle copy- } \\
\text { right issues }\end{array}$ & .25 & -.07 & .83 & 2.39 & 1.0675 \\
\hline$\%$ explained variance & 29.1 & 25.5 & 13.5 & & \\
\hline
\end{tabular}

TABLE V.

INCENTIVES FOR CREATING OER - DIMENSIONALITY AND DESCRIPTIVE DATA

\begin{tabular}{|c|c|c|c|c|c|}
\hline & ACAG & SOBE & $\mathbf{M}$ & SD $^{A}$ & $\mathbf{N}$ \\
\hline I want to gain in reputation & .84 & -.03 & 2.20 & 1.08 & 36 \\
\hline $\begin{array}{l}\text { It is a way to stimulate im- } \\
\text { provement, innovation and reuse } \\
\text { in my institution }\end{array}$ & .80 & .14 & 3.06 & 0.95 & 36 \\
\hline I want to collaborate with peers & .75 & .34 & 3.09 & 1.04 & 36 \\
\hline $\begin{array}{l}\text { I believe it is a good way to } \\
\text { increase the recruitment of } \\
\text { students }\end{array}$ & .55 & .27 & 2.57 & 1.04 & 36 \\
\hline $\begin{array}{l}\text { I want to share this for the bene- } \\
\text { fit of others }\end{array}$ & .03 & .91 & 3.56 & 0.61 & 36 \\
\hline $\begin{array}{l}\text { I want to transfer theoretical } \\
\text { research results into practical } \\
\text { applications }\end{array}$ & .34 & .79 & 3.51 & 0.69 & 36 \\
\hline$\%$ explained variance & 38.8 & 27.6 & & & \\
\hline
\end{tabular}

TABLE VI.

DIFFERENCE IN FACTOR POINTS BETWEEN THEACHERS IN ANIMAL WELFARE AND OTHER TEACHERS

\begin{tabular}{lccc}
\hline & Animal welfare & Other & P-Value \\
\hline Benefits & & & \\
Outreach & $0.28 \pm 0.82$ & $-0.12 \pm 1.05$ & 0.062 \\
Collective & $0.16 \pm 0.97$ & $-0.07 \pm 1.01$ & 0.312 \\
Expansive & $-0.1 \pm 1.13$ & $0.01 \pm 0.95$ & 0.942 \\
\hline Problems & & & \\
Quality assessment & $-0.34 \pm 1.12$ & $0.19 \pm 0.89$ & 0.087 \\
Pedagogical adaptability & $-0.25 \pm 0.99$ & $0.14 \pm 0.99$ & 0.179 \\
Deviant object & $-0.34 \pm 0.78$ & $0.19 \pm 1.07$ & 0.042 \\
\hline Incentives & & & \\
Collective and collaborative & $0.09 \pm 1.00$ & $-0.04 \pm 1.01$ & 0.566 \\
Expectations & $0.09 \pm 1.07$ & $-0.04 \pm 0.98$ & 0.592 \\
\hline Barriers & & & \\
Quality assessment & $-0.10 \pm 0.95$ & $0.05 \pm 1.03$ & 0.575 \\
Pedagogical adaptability & $-0.33 \pm 0.78$ & $0.16 \pm 1.06$ & 0.039 \\
Confidence in own compe- & $-0.09 \pm 0.85$ & $0.05 \pm 1.07$ & 0.574 \\
tence & & & \\
\hline Incentives for creation & & & \\
Academic agency & $0.18 \pm 1.00$ & $-0.16 \pm 1.00$ & 0.373 \\
Societal benefits & $0.32 \pm 0.65$ & $-0.28 \pm 1.18$ & 0.120 \\
\hline
\end{tabular}


TABLE VII.

DIFFERENCES IN ADOPTION AND VIEW ON QUALITY BETWEEN ANIMAL WELFARE TEACHERS AND OTHER TEACHERS

\begin{tabular}{|c|c|c|c|c|c|}
\hline & $\%$ & $\mathbf{N}$ & $\begin{array}{c}\text { Animal } \\
\text { welfare } \\
(\%)\end{array}$ & $\begin{array}{l}\text { Other } \\
(\%)\end{array}$ & P-Value \\
\hline Use Internet in teaching & 67 & 101 & 70 & 66 & 0.710 \\
\hline Use OER & 46 & 76 & 62 & 40 & 0.088 \\
\hline Create OER & 33 & 86 & 58 & 22 & 0.001 \\
\hline Re-mix OER before use ${ }^{A}$ & 33 & 73 & 43 & 28 & 0.191 \\
\hline $\begin{array}{l}\text { Want quality approach } \\
\text { based on peer review }\end{array}$ & 73 & 75 & 74 & 73 & 0.940 \\
\hline $\begin{array}{l}\text { Allowing students to modi- } \\
\text { fy is unacceptable }\end{array}$ & 12 & 75 & 4 & 15 & 0.175 \\
\hline $\begin{array}{l}\text { Allowing students to modi- } \\
\text { fy is risky }\end{array}$ & 49 & 75 & 35 & 56 & 0.094 \\
\hline $\begin{array}{l}\text { Should be overlooked by } \\
\text { faculty }\end{array}$ & 34 & 75 & 30 & 37 & 0.609 \\
\hline $\begin{array}{l}\text { Allowing students to modi- } \\
\text { fy is of high importance for } \\
\text { student engagement }\end{array}$ & 25 & 75 & 39 & 19 & 0.068 \\
\hline $\begin{array}{l}\text { Allowing students to modi- } \\
\text { fy is not a big issue }\end{array}$ & 12 & 75 & 35 & 2 & 0.000 \\
\hline
\end{tabular}

\section{A. Adoption of OER}

The adoption of OER in the academic year 2011-2012 was based on self-reporting (Table VII). In the past academic year $67 \%$ of the respondents used Internet, $46 \%$ used OER and 33\% had sometimes been involved in the creation of OER. There was a positive correlation between use and creation of OER $(\mathrm{p}<0.001)$; respondents who had used OER had also created OER. Of those teachers who used OER, one third re-mixed the OER before use. Teachers in the subject of animal welfare were more involved in the creation of OER than others $(p<0.001)$, but there was no significant difference in the use of OER between teachers in animal welfare and teachers in other subjects. The respondents were asked to specify which OER they had used. Every animal welfare teacher indicated that when they had used OER they were developed by peers in their university or different universities; other teachers used YouTube clips, OER developed by private training providers, and OER developed by other governmental authorities as well as OER developed in their universities.

The majority of the responders $(73 \%)$ wanted a quality approach for OER based on peer-review. Allowing student to modify and add on OER was found to be unacceptable by $12 \%$ of the respondents, $49 \%$ found it risky and $34 \%$ emphasized that it should be overlooked by teachers. Twenty-five percent found that allowing students to modify is of high importance for student engagement and $12 \%$ did not find student modifications to be a big issue. Teachers in animal welfare seemed to have higher acceptance than other respondents for allowing students to modify because it was "not a big issue" $(p<0.001)$, but they supported peer review as much as others.

\section{DISCUSSION}

The results of this study indicated that the value of OER and the adoption of OER could not be explained by teachers' subject areas alone, but had complex underlying explanations. Earlier studies have used the activity theory to help understand the "variability in adoption patterns when it comes to the activities and purposes for which ICT is being used" [46, p. 185].

Activity theory $[25 ; 44]$ is used in this study to map out the underlying dimensions for the respondents' motives in order to make the adoption patterns of OER visible and to provide sufficient context to be able to make generalization possible [4]. Firstly, we discuss the individual motivations are secondly the adoption of OER, seen as a collaborative activity between individuals with different motivations.

\section{A. Value of OER}

Moving down and inward, the activity theory "tackles issues of subjectivity, experiencing, personal sense, emotion, embodiment, identity, and moral commitment" [44, p. 22]. Hence, in order to better understand the activities of these teachers, their motivations and their conditions for and goals of activities need to be included in the analysis [47]. The activities are motivated by the need to transform the object, and the motivations of teachers give sense and direction to those activities, e.g. by encouraging or limiting the uptake of technology in teaching practices [38].

From the factor analysis, teachers' underlying dimensions of motives to adopt OER divided to benefits, incentives, problems and barriers. The underlying factors varied as shown in figure 1.

Three underlying factors as benefits for using OER were identified; 1) outreach reason, 2) collective reason, and 3) expansive reason. The outreach reason has a strong democracy dimension, which may be linked to altruism.

These three underlying factors can be seen as an expression of the three planes of activities identified by [55]; the internal, the interpersonal and the external planes.

Altruism has been found to be the most important predictor for teachers' intentions to share OER [3]. Altruism is expressing satisfaction of the behaviour as such without the need of any external rewards, which is in strong contrast to gaining reputation, and is a motivation to people for reasons which are external to the behaviour itself [2]. At an institutional level "free education for everybody according to the UN declaration" is the most important incentive according to OECD [49] followed by effective use of taxpayers' money, promotion of lifelong learning, show casing the institution for new students and stimulation of internal improvement and re-use. Apart from the statement on taxpayers' money (which many responders in this study did not understand and therefore this item was omitted), these incentives were also of highest importance within this study. The most important incentive for the creation of OER was also the altruistic statement that "I want to share this for the benefit of others".

Teachers in animal welfare tended to have more altruistic incentives to create OER than other teachers, and the altruistic incentives were strongly correlated with the actual creation of OER. This correlation is interesting,

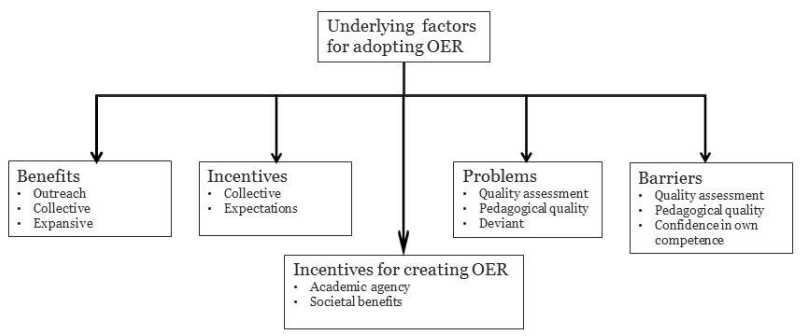

Figure 1. Underlying factors to consider for OER adoption 
though the present study does not allow an analysis of causal relations. That intrinsic factors, especially altruism, were critical for the inclination to share, confirmed the results from a previous study [3], and ref [50] has pointed at a "feel-good factor" as a motivation for OEP, explained both by altruism and for joining the movement.

The collective factor identified in this study may be linked to satisfaction. This motivation can be found in what is conceptualised as an affinity space for teachers who share the same concerns and collaborate on OER [14; 15]. It has also been found that if a shared OER is used and appreciated, the creator will be more inclined to share in the future [2]. Many responders emphasized the collective aggregation of knowledge, which can be seen as satisfaction related to the act of shaping meaningful action [14] between participants with mutual engagement.

This collective attitude can also be seen as a process of peer-assistance within affinity spaces [53]; that peers help each other to deal with aspects of the subject, which they personally did not master. These results support the hypothesis by [8] that the OER trend is most vigorous when situated in niche communities within specific disciplines in highly motivated networks.

The underlying factor identified as an expansive teaching approach is an institutional interpretation of the potential of OER for expanding higher education. This could be for lifelong learning and reaching new target groups [11].

The factor analysis also identified two underlying factors for personal incentives, which both seemed to represent all three planes of activity, personal satisfaction related to the collaboration with peers, interpersonal collaborative activities and collective global activities for knowledge sharing.

One was focusing on higher education as a collective enterprise, which is an expression of the basic idea that higher education should be research based. It can be interpreted as by utilizing the contributions of the expertise of others to go beyond their own capabilities, it is a way to increase coverage of a topic, which has also been found as an important incentive in other studies [48, 53].

The second identified incentive was linked to the internal and external expectations on OER. The respondents have their academic freedom which may be in contrast to both internal and external expectations, as reflected to some degree in the mean scores. However, satisfying students seems to be a rather strong incentive. The internal expectations can be to adapt modern teaching practices with the argument to attract more students and be more effective. This view is in line with the incentive that OER can stimulate institutional development, innovation and reuse [49]. The external expectations are in the personal incentives expressed as OER being an instrument to develop own teaching and to attract more students to own courses, thus being able to reach beyond existing boarders of formal education [51].

The factor analysis defined three underlying problems at general level and barriers at personal level, of which two were the same. They were concerns for the quality assessment, since dynamic OER are challenging the established structures such as the peer review system [51], and concerns for the pedagogical adaptability related to the disruptive character of OER, which requires an effort to adapt it to the target group and local context [46]. This has also been described by [52, p. 442] as "technology was perceived more as an additional problem than as a solution". The third underlying concern was at a systemic level seeing OER as threatening the robustness of the academy and at the personal level questioning the individual competence and need of further training for being able to adopt OER; both issues have been described as general concerns in a review of quality issues related to OER [53].

However, animal welfare teachers did not find the OER being challenging the social norms and rules in the otherwise robust academy to the same degree as other teachers did; and they did not find the same problems with pedagogical adaptability as others. Both results suggest that these teachers constitute a sub community having own norms. The internal planes of activity seems even linked to their external planes of activity, since they have higher adoption rate of OER. Although we have not been able to find causal relations between motivation and adoption.

That copy-right issues were the most significant problems and barriers were expected, since copy-right has been categorised as a persistent challenge to OER, but copy-right related to OER seems to be a question of making creative common licences widely known [51]. One can speculate whether the copy-right issues are subordinate activities and therefore when frustrated, individuals change their actions to learn more about copy-right as a new goal. The second, third and fourth most important problems and barriers were all related to the quality of OER. These challenges have been categorised as sticking points, described as challenges to existing models and measures [51], and are expected to be more severe since they frustrate the motivations.

Beyond the identified problems and barriers the coordination of different motivations and agencies within an activity system may give rise to contradictions or systemic tensions. The motivations may be interlinked through relations of conflict, power and resistance, and it can be a struggle to align the motives and thus coordinate the activities [54]. This may trigger innovation and change in collaborative activity and is a source of development [25]. Teachers' adoption of OER may therefore generate institutional teaching development and is sometimes dependent on institutional support [50].

The factor analysis on incentives for the creation of OER expressed that adoption is not only to use/reuse but also to participate in OER creation. Two underlying factors were found. One expressed systemic academic agency with emphasis on strategic development, possible through a dialogue with society, and collaboration with peers. The other factor expressed concerns for societal benefits of knowledge sharing with emphasis on democratic reasons and the more disruptive characters of OER in higher education. These incentives were the same across subject areas and are in line with the results from a review of quality issues related to OER concluding that the processes of peer-assistance within higher education need to be strengthened [53].

In summary, the teachers in this study had different motivations, or underlying motives, to adopt OER. The study indicated that teachers in animal welfare had different motivations both related to individual and systemic issues than other teachers. The differences may be explained by this subject area, attracting teachers which are passionate about their work and expressing strong emotional commitment for the welfare of animals and for the sharing of 
knowledge with other individuals. Since it is a relative small network of teachers their individual motives may be linked and sometimes they may be actors in collaborate activities. As a result we suggest that the teachers in animal welfare participate in a distinct affinity space with its own norms and conventions that seems to be supportive to OER adoption.

\section{B. Adoption of OER}

Moving up and outward, the activity theory tackles learning networks of interconnected activity systems [44, p. 22]. Here we analyse actions at the external plane related to the OER as material products, for example how the respondents adopt OER (creation, use or remix) and if they act differently oriented to the goal.

In this study the use of OER in the preceding academic year was mirroring the general low rate of adoption of OER in educational practices $[16 ; 48]$. The results on creation and reusing confirmed that these practices are more frequent activities than re-mixing and redistribution of new and adapted versions [1].Thus, judging by the respondents' answers on adoption, the majority of the OER in this study are not collective in a general sense but may be collaborative in the phase, when the OER is initially created, and afterwards handled as artefacts.

It seems like animal welfare teachers wanted to create OER collectively because they on the one hand wanted to share for the benefit of others and on the other to collaborate with peers. Animal welfare is a scientific domain which is relatively new and expanding and therefore it attracts teachers with a great deal of enthusiasm and a will to improve teaching practices and reach beyond the borders of the traditional higher education. At the same time animal welfare is a contested subject area, under constant debate and review by academics and legislators worldwide, since new scientific knowledge about animal cognition and their ability to feel pain increase our moral circle for taking into consideration animals as a vulnerable group.

Teachers in the subject of animal welfare are more likely to adopt OER than other teachers. The difference may be related to the value of OER within this subject area, which 1) is acting both globally and locally and 2) needs measures to both glue together individuals by collective activities and reach beyond the borders of the network by attracting new individuals and be in dialogue with society. Teachers in this specific and contested subject area are acting at the boundary between the activity system of their scientific community and a multitude of other activity systems with conflicting agencies and motivations.

The specific OER used in this study by animal welfare teachers were developed by peers in the same or other universities or in cooperation between universities, which was not the case for other teachers, who used OER of different origin. This confirms that trust is important for re-using of OER [1]. Accordingly, an affinity space may be necessary to accomplish the feeling of trust and peerassistance [53]. Since trust is important for the degree of reuse, one could expect that reputation is important for engagement in the development and sharing of OER. However, this study confirms previous research indicating that reputation is not an incentive for the creation and sharing of OER, which mainly seemed to depend on altruistic motivations [2].
Finally, the respondents trusted peer review as an instrument for quality assessment. Peer review is a generally accepted quality instrument seeking to maintain academic standards [53] and is trusted among teachers [1]. Allowing students to undertake changes were associated with some risk for half of the respondents. However, the teachers in animal welfare did not find it to be such a significant question, and the survey suggests that increased student motivation can explain this response.

\section{CONCLUSION}

The main objectives of this article were twofold. First, to examine benefits, personal incentives, problems and personal barriers for the adoption of OER, and second, to investigate if teaching animal welfare is related to a higher degree of OER adoption compared to teaching a broader subject area of animal and food science. The study confirms that the adoption of OER is part of a culture of sharing and that OER challenge the individual teacher as well as the boundaries of higher education by placing diverse demands on quality assessment and teaching practices. However, it has to be borne in mind that these conclusions are grounded in a small sample based on self-reporting and that no causal relationships between motivation and adoption are found.

Adoption of OER was associated with positive motivations about collaboration and inclusiveness. Teachers wanted to engage in knowledge sharing because they wanted to collaborate with peers and to some degree because of democratic reasons. The disruptive nature of OER was related to both the positive and negative motivations for OER adoption. Underlying explanation related to using OER to expand the boundaries of higher education and meet internal and external expectations were positive, whereas the reverse depicts feelings of OER as something that does not belong in the academy and of low confidence in own competence.

The respondents' motivations may have predicting power to their activities, since altruistic motivations were significantly correlated to the actual creation of OER; but the creation of OER was not perceived as a way to gain in reputation, which is in line with previous findings [2].

Teachers in the subject of animal welfare were more involved in OEP and had different motivations to adopt OER than respondents in broader and less contested subject areas. Thus, we have identified an affinity space between the responders, who tended to engage in knowledge sharing because of altruistic motivations and used OER developed by peers, which can be an expression of trust [1] and peer-assistance [53]. The trust in peer review is generally accepted but higher acceptance for student involvement in affinity spaces needs further research.

The results supported the role of content-based practices and passions for trust and willingness to share and collaborate [6], and the findings about teachers in the subject of animal welfare may be an expression of that affinity spaces are prerequisites for enacted agency and breaching boundaries.

\section{ACKNOWLEDGMENT}

We want to thank Cheryl Hodgkinson-Williams, Berner Lindström, and Marisa Ponti for helpful comments on a previous version of this manuscript. 


\section{REFERENCES}

[1] Clements, K.I. and Pawlowski, J.M. (2011). User-oriented quality for OER: understanding teachers' views on re-use, quality, and trust. Journal of Computer Assisted Learning, 28, 4-14. Blackwell Publishing Ltd. http://dx.doi.org/10.1111/j.1365-2729.2011. 00450.x

[2] Van Acker, F, van Buuren, H., Kreijns, K. and Vermeulen, M. (2013). Why teachers share educational resources: A social exchange perspective. In: McGreal, R., Kinuthia, W. and Marshall, S. (Eds.) Open Educational Resources: Innovation, Research and Practice. 177-191. Vancouver, Commonwealth of Learning and Athabasca University. December 2014. http://www.col.org/ resources/publications/Pages/detail.aspx?PID $=446$

[3] Tromp, G.W. and Long, P.D. (2013). Why do people share content? Identifying why students support sharing course material, Open Learning: The Journal of Open, Distance and e-Learning, 28:1, 21-35. December 2014. http://dx.doi.org/10.1080/02680513. 2013.783768

[4] Kirkwood, A. T. and Price, L. (2014). Technology-enhanced learning and teaching in higher education: what is "enhanced" and how do we know? A critical literature review. Learning, Media and Technology, 39 (1), 6-36. December 2014 http://dx.doi.org/10.1080/17439884.2013.770404

[5] ROER4D (2013). Research into Open Educational Resources for Development in Post-secondary Education in the Global South (ROER4D): Proposal. December 2014. http://roer4d.org/wpcontent/uploads/2014/05/ROER4D-Proposal-May-2013.pdf

[6] Ajzen, I. and Fishbein, M. (1980). Understanding attitudes and predicting social behaviour. Prentice-Hall, N.J. Englewood Cliffs.

[7] Pegler, C. (2012). Herzberg, hygiene and the motivation to reuse: Towards a three-factor theory to explain motivation to share and use OER. Journal of Interactive Media in Education, 2012 (01). http://dx.doi.org/10.5334/2012-04

[8] Petrides, L., Nguyen, L., Jimes, C. and Karaglani, A. (2008). Open educational resources: inquiring into author use and reuse. Int. J. Technology Enhanced Learning, 1(1-2), 98-117. December 2014. http://inderscience.metapress.com/content/9428665670616423/ http://dx.doi.org/10.1504/IJTEL.2008.020233

[9] Downes, S. (2007) Models for sustainable open educational resources. Interdisciplinary Journal of Knowledge and Learning Objects 3, 29-44. December 2014. http://www.ijklo.org/Volu me3/IJKLOv3p029-044Downes.pdf

[10] Bonaccorsi, A. and Rossi, C. (2003). "Why Open Source software can succeed". Open Source Software Development 32(7), 12431258. December 2014. http://dx.doi.org/10.1016/S00487333(03)00051-9

[11] Brown, J. S., and Adler, R. (2008). Minds on fire: Open education, the long tail, and learning 2.0. Educause Review, 43, 1.

[12] Iiyoshi, T. and Kumar, M.S.V. (2008). Opening up education. The collective advancement of education through open technology, open content, and open knowledge. The MIT Press, Massachusetts, USA.

[13] Gee, J. P. (2004). Situated Language and Learning: A Critique of Traditional Schooling. New York: Routledge.

[14] Gee, J. P., and Hayes, E. (2011). "Nurturing Affinity Spaces and Game-Based Learning." Cadernos de Letras (UFRJ) 28. December 2014. http://www.letras.ufrj.br/anglo germanicas/cadernos/numer os/072011/textos/cl2831072011gee.pdf

[15] Ponti, M. (2014). Self-directed learning and guidance in nonformal open courses, Learning, Media and Technology, 39:2, 154168, December 2014. http://dx.doi.org/10.1080/17439884 .2013 .799073

[16] Atenas, J. and Havemann, L. (2013). Quality assurance in the open: an evaluation of OER repositories. INNOQUAL - International Journal for Innovation and Quality in Learning 1 (2), 22-34. ISSN2294-9763. December 2014. http://eprints.bbk.ac.uk/8609/

[17] Broom, D. M. (2005). Animal Welfare Education: Development and Prospects. Journal of Veterinary Medicine; 32(4), 438-441. http://dx.doi.org/10.3138/jvme.32.4.438

[18] Algers, A., Lindström, B. and Pajor, E.A. (2011). A New Format for Learning about Farm Animal Welfare. Journal of Agricultural and Environmental Ethics: 24(4), 367-379. Springer. Guelph, University of Guelph. http://dx.doi.org/10.1007/s10806-010-9271-5
[19] Broom, D. M. (2009). Animal welfare and legislation. In: J. M. Smulders and B. Algers (Eds.), Food safety assurance and veterinary public health. Vol. 5, 339-350. Welfare of production animals: assessment and management of risks. ISBN: 978-90-8686122-4. The Netherlands: Wageningen Academic Publishers

[20] Special Eurobarometer (2007). Attitudes of EU citizens towards Animal Welfare. December 2014. http://ec.europa.eu/public opinion/archives/ebs/ebs_270_en.pdf

[21] Hewson C.J., Baranyiova, E., Broom, D. M., Cockram, M. S., Galindo, F., Hanlon, A. J., ... and Waldau, P. (2005). Approaches to teaching animal welfare at 13 veterinary schools worldwide. Journal of Veterinary Medical Education 32, 422-437. http://dx.doi.org/10.3138/jvme.32.4.422

[22] Sfard, A. (1998). On two metaphors for learning and the dangers of choosing just one. Educational researcher, 27(2), 4-13. http://dx.doi.org/10.3102/0013189X027002004

[23] Geith, C., Vignare, K., Bourquin, L. D., and Thiagarajan, D. (2010). Designing Corporate Training in Developing Economies Using Open Educational Resources. Journal of Asynchronous Learning Networks, 14(3), 3-12.

[24] Frydenberg, J. (2009). Distance education and its potential for international co-operative education. Revue scientifique et technique (International Office of Epizootics), 28(2), 839-845.

[25] Engeström, Y. (1987). Learning by expanding: an activitytheoretical approach to develop mental research. Diss. Helsinki: Univ.

[26] Cox, G. (2013). Researching Resistance to Open Education Resource Contribution: An Activity Theory Approach. E-Learning and Digital Media, 10(2), 148-160. http://dx.doi.org/10.2304/ elea.2013.10.2.148

[27] Dumoulin, E. (2004). Trends in food science education in Europe. Journal of Food Science, 69(3), 98-99. http://dx.doi.org/10.1111/ j.1365-2621.2004.tb13349.x

[28] Iwaoka, W. T., Britten, P., and Dong, F. M. (1996). The changing face of food science education. Trends in Food Science \& Technology, 7(4), 105-112. http://dx.doi.org/10.1016/0924-2244(96) 10014-5

[29] Harper, W. J., Courtney, P. D. and Chism, G. W. (2003). An immersion approach to teaching food science. Journal of Food Science Education, 2(3), 53-56. http://dx.doi.org/10.1111/j.15414329.2003.tb00027.x

[30] Shanley, E. L., Thompson, C. A., Leuchner, L. A. and Zhao, Y. (2004). Distance education is as effective as traditional education when teaching food safety .Food Service Technology, 4(1), 1-8. http://dx.doi.org/10.1111/j.1471-5740.2003.00071.x

[31] Kaneene, J. B., Ssajjakambwe, P., Kisaka, S., Miller, R. and Kabasa, J. D. (2013). Creating Open Education Resources for Teaching and Community Development through Action Research: An Overview of the Makerere AgShare Project. Journal of Asynchronous Learning Network 17(2).

[32] Eurobarometer, F. (2009). 256. European's attitudes towards the issue of sustainable consumption and production. Conducted by The Gallup Organisation, Hungary at the request of the Directorate-General for the Environment. European Commission.

[33] Fraser, D. (2008). Understanding Animal Welfare. The Science in its Cultural Context (UFAW Animal Welfare). Chichester, WileyBlackwell. http://dx.doi.org/10.1186/1751-0147-50-S1-S1

[34] Broom, D. M. (2010). Animal welfare: An aspect of care, sustainability, and food quality required by the public. Journal of veterinary medicine 37(1), 83-88. $\quad$ http://dx.doi.org/10.3138/ jvme.37.1.83

[35] Algers, B. (2011). Animal welfare - recent developments in the field. CAB Reviews: Perspectives in Agriculture, Veterinary Science, Nutrition and Natural Resources No 6, No. 010.

[36] Wals, A. E. (Ed.). (2007). Social learning: towards a sustainable world: principles, perspectives, and praxis. Wageningen Academic Pub.

[37] Fraser, D. (1999). Animal ethics and animal welfare science: bridging the two cultures. Applied Animal Behaviour Science; 65, 171-89. December 2014. http://www.sciencedirect.com/science/ article/pii/S0168159199000908\# http://dx.doi.org/10.1016/S01681591(99)00090-8 
[38] Blin, F. and Munro, M. (2008). Why hasn't technology disrupted academics' teaching practices? Understanding resistance to change through the lens of activity theory. Computers \& Education, 50(2), 475-490. http://dx.doi.org/10.1016/j.compedu. $\underline{2007.09 .017}$

[39] Hashim, N. H. and Jones, M. L. (2007). Activity Theory: A framework for qualitative analysis. Faculty of Commerce-Papers, 408.

[40] Said, M. N. H. M., Tahir, L. M., Ali, M. F., Noor, N. M., Atan, N. A. and Abdullah, Z. (2014). Using Activity Theory as Analytical Framework for Evaluating Contextual Online Collaborative Learning. International Journal of Emerging Technologies in Learning (iJET), 9(5), 54-59. http://dx.doi.org/10.3991/ ijet.v9i5.3972

[41] Vygotsky, L.S. (1978). Mind in society: The psychology of higher mental functions. Cambridge: Harvard University Press.

[42] Säljö, R. (2010). Digital tools and challenges to institutional traditions of learning: technologies, social memory and the performative nature of learning. Journal of Computer Assisted Learning, 26, 53-64. http://dx.doi.org/10.1111/j.1365-2729.2009. 00341.x

[43] Ehlers, U. D. and Conole, G. C. (2010). Open Educational Practices: Unleashing the power of OER. Paper presented to UNESCO Workshop on OER in Namibia 2010. Windhoek.

[44] Engeström, Y. and Sannino, A. (2010). Studies of expansive learning: Foundations, findings and future challenges. Educational Research Review, 5(1), 1-24. http://dx.doi.org/10.1016/ j.edurev.2009.12.002

[45] Edwards, A. and Kinti, I. (2010). Working relationally at organisational boundaries. Negotiating expertise and identity. In: Daniels, H., Edwards, A., Engeström, Y. Gallagher, T. and Ludvigsen, S.R. (Eds.) Activity Theory in Practice. Promoting learning across boundaries and agencies. 126-139. ISBN 0-415-47724-7 Routledge, Oxon, UK.

[46] Kirkup, G. and Kirkwood, A. (2005). Information and communications technologies (ICT) in Higher Education teaching - a tale of gradualism rather than revolution. Learning, Media and Technology, 30(2), 185-199. http://dx.doi.org/10.1080/1743988 0500093810

[47] Kaptelinin, V. (1996). Activity theory: Implications for humancomputer interaction. Context and consciousness: Activity theory and human-computer interaction, 103-116.

[48] Atenas, J., Havemann, L. and Priego, E. (2014). Opening teaching landscapes: The importance of quality assurance in the delivery of open educational resources. Open Praxis, 6(1), 29-43. http://dx.doi.org/10.5944/openpraxis.6.1.81

[49] OECD (2007). Giving knowledge for Free - the Emergence of Open Educational Resources, no 3, pp. 153. Paris, France. December 2014. www.sourceoecd.org/education/9789264031746
[50] McAndrew, P. (2006) Motivations for OpenLearn: The Open University's open content initiative. Paper presented at the OECD experts meeting on Open Educational Resources. October 26-27, Barcelona. December 2014. http://kn.open.ac.uk/public/ document.cfm?docid $=8816$

[51] McAndrew, P. and Farrow, R. (2013). Open Educational Research: From the practical to the theoretical. In: McGreal, R., Kinuthia, W. and Marshall, S. (Eds.) Open Educational Resources: Innovation, Research and Practice. 65-78. Vancouver, Commonwealth of Learning and Athabasca University.

[52] Karasavvidis, I. (2009). Activity Theory as a conceptual framework for understanding teacher approaches to Information and Communication Technologies. Computers \& Education, 53(2), 436-444. http://dx.doi.org/10.1016/j.compedu.2009.03.003

[53] Camilleri, A. F., Ehlers, U. D. and Pawlowski, J. (2014). State of the Art Review of Quality Issues related to Open Educational Resources (OER). December 2014. http://dx.doi.org/10.2791/80171

[54] Kaptelinin, V., and Nardi, B. A. (2006). Activity theory in a nutshell. Acting with technology: Activity Theory and interaction design, 29-72.

[55] Yamagata-Lynch, L. C. (2010). Understanding cultural historical activity theory. In Activity Systems Analysis Methods, 13-26. Springer US.

[56] Rogoff, B. (1995). Observing http://dx.doi.org/10.1007/978-14419-6321-5 2 2 sociocultural activity on three planes: Participatory appropriation, guided participation, apprenticeship. In J. V. Wertsch, A. Alvarez \& P. del Rio (Eds.), Sociocultural studies of mind (139-164). Cambridge, UK: Cambridge University Press.

[57] Kaptelinin, V. (2005). The object of activity: Making sense of the sense-maker. Mind, Culture, and Activity, 12(1), 4-18. http://dx.doi.org/10.1207/s15327884mca1201_2

[58] Leontiev, A. N. (1981). Problems of the development of the mind. Moscow: Progress. (Original work published 1959).

\section{AUTHORS}

A. Algers is with Department of Food Science, Swedish University of Agricultural Sciences at Swedish University of Agricultural Sciences, P O Box 234, 53223 Skara, Sweden (e-mail: anne.algers@slu.se)

A. Silva-Fletcher is with Royal Veterinary College, Hawkshead Lane, Hatfield, AL9 7TA, UK (e-mail: ASilvaFletcher@RVC.AC.UK)

Submitted 31 January 2015. Published as resubmitted by the authors 24 March 2015. 